\title{
Phosphorylation at serines 104 and 106 by Erk1/2 MAPK is important for estrogen receptor- $\alpha$ activity
}

\author{
Ross S Thomas, Naveed Sarwar, Fladia Phoenix, R Charles Coombes and Simak Ali \\ Cancer Research UK Laboratories, Department of Oncology, Imperial College London, Hammersmith Hospital, Du Cane Road, London W12 ONN, UK \\ (Correspondence should be addressed to S Ali; Email: simak.ali@imperial.ac.uk)
}

\begin{abstract}
Phosphorylation of estrogen receptor- $\alpha(E R \alpha)$ at specific residues in transcription activation function 1 (AF-1) can stimulate $E R \alpha$ activity in a ligand-independent manner. This has led to the proposal that AF-1 phosphorylation and the consequent increase in $\mathrm{ER} \alpha$ activity could contribute to resistance to endocrine therapies in breast cancer patients. Previous studies have shown that serine 118 (S118) in AF-1 is phosphorylated by extracellular signal-regulated kinases 1 and 2 (Erk1/2) mitogen-activated protein kinase (MAPK) in a ligand-independent manner. Here, we show that serines 104 (S104) and 106 (S106) are also phosphorylated by MAPK in vitro and upon stimulation of MAPK activity in vivo. Phosphorylation of S104 and S106 can be inhibited by the MAP-erk kinase (MEK)1/2 inhibitor U0126 and by expression of kinase-dead Raf1. Further, we show that, although $\mathrm{S} 118$ is important for the stimulation of ER $\alpha$ activity by the selective ER modulator 4-hydroxytamoxifen (OHT), S104 and S106 are also required for the agonist activity of OHT. Acidic amino acid substitution of $\mathrm{S} 104$ or $\mathrm{S} 106$ stimulates $\mathrm{ER} \alpha$ activity to a greater extent than the equivalent substitution at $\mathrm{S} 118$, suggesting that phosphorylation at $\mathrm{S} 104$ and $\mathrm{S} 106$ is important for $\mathrm{ER} \alpha$ activity. Collectively, these data indicate that the MAPK stimulation of ER $\alpha$ activity involves the phosphorylation not only of S118 but also of S104 and S106, and that MAPK-mediated hyperphosphorylation of ER $\alpha$ at these sites may contribute to resistance to tamoxifen in breast cancer.

Journal of Molecular Endocrinology (2008) 40, 173-184
\end{abstract}

\section{Introduction}

Estrogen receptor- $\alpha(\mathrm{ER} \alpha)$ is a member of the nuclear receptor superfamily of ligand-regulated transcription factors, and is required for development and maintenance of the female and male reproductive systems, bone, and cardiovascular system, as well as being significant for certain brain functions (Couse \& Korach 1999). Additionally, estrogens stimulate breast cancer progression and $\sim 70-80 \%$ of breast cancers express $\mathrm{ER} \alpha$. The presence of $\mathrm{ER} \alpha$ correlates with likelihood of response to anti-estrogens, such as tamoxifen (Osborne 1998), and to aromatase inhibitors that inhibit estrogen biosynthesis (Henderson \& Piccart-Gebhart 2005), demonstrating the importance of ER $\alpha$ in breast cancer progression. However, a proportion of patients with $\mathrm{ER} \alpha$ positive disease do not respond to endocrine therapy. Further, of those patients who respond, many who initially present with localized disease, and all with advanced breast cancer, relapse. Most resistant tumors remain $\mathrm{ER} \alpha$-positive and frequently respond to alternative antiestrogen treatment, indicative of a continued role for $\mathrm{ER} \alpha$ in breast cancer cell proliferation (Ali \& Coombes 2002). Augmentation of ER $\alpha$ activity in the presence of estrogen or anti-estrogens, and/or ligand-independent activation of $\mathrm{ER} \alpha$, could provide an important mechanism for resistance to anti-estrogen therapies. In agreement with this possibility, a recent study shows that levels of S118 phosphorylation are increased following breast cancer recurrence following tamoxifen treatment (Sarwar et al. 2006).

$\mathrm{ER} \alpha$ regulates gene expression through direct binding to estrogen-response elements within the promoters of estrogen-regulated genes, or by recruitment to DNA through interaction with other transcription factors (Gronemeyer 1991, Bjornstrom \& Sjoberg 2005). Transcriptional regulation by $\mathrm{ER} \alpha$ is partly mediated by transcription activation function, AF-2, which is intrinsic to the ligand-binding domain (LBD). Estrogen binding to the LBD results in a conformational change that allows recruitment of coactivators to the LBD (Brzozowski et al. 1997, Shiau et al. 1998, Glass \& Rosenfeld 2000). A second transcription activation function, AF-1, is encoded within the N-terminal 180 amino acids. AF-1 activity is promoter and cellular context dependent (Tzukerman et al. 1994), and can be influenced by the expression profile of specific coactivators (Smith et al. 1997). Although there is evidence to suggest that phosphorylation of AF-1 alone can enhance activity (Bunone et al. 1996, Ignar-Trowbridge et al. 1996), ligand binding to AF-2 can also induce AF-1 activity (Metzger et al. 1992). This suggests that, in a basal state, AF-1 activity is blocked by AF-2. Finally, AF-1 and AF-2 can act synergistically in a 
promoter- and cell-specific manner (Gronemeyer 1991, Tsai \& O’Malley 1994, Beato et al. 1995).

Tamoxifen is an example of a mixed estrogen agonist/antagonist, also termed selective ER modulators, which has been proposed to act by inhibiting the LBD/AF-2, whilst allowing activation of AF-1 (Berry et al. 1990, McDonnell et al. 1995, Brzozowski et al. 1997, Shiau et al. 1998). Structural studies have indicated that the inhibition of the LBD/AF-2 in the tamoxifen-bound $\mathrm{ER} \alpha$ is due to the positioning of helix 12 in the hydrophobic cleft to which transcriptional coactivators, such as the p160 family members, are recruited, thereby preventing coactivator recruitment. The same cleft can also be involved in corepressor binding, and tamoxifen has been suggested to allow corepressor recruitment to the LBD (Nettles \& Greene 2005). The nature of AF-1 activation by ligands such as tamoxifen, and in the absence of ligand, is unknown, but may involve phosphorylation of ER $\alpha$. Previous studies have shown that in ovariectomized mice, uterine proliferation (which is normally estrogen- dependent) can be mediated by growth factors such as epidermal growth factor (EGF), and that the EGF-mediated uterine stimulation is ER $\alpha$ dependent (Ignar-Trowbridge et al. 1992, Curtis et al. 1996). ER $\alpha$ may become phosphorylated in response to EGF and other growth factors, resulting in ligand-independent ER $\alpha$ activation (IgnarTrowbridge et al. 1993).

Phosphorylation site mapping has demonstrated that serine 118 (S118) in AF-1 is phosphorylated by Erk1/2 MAPK, resulting in stimulation of ER $\alpha$ activity (Kato et al. 1995, Bunone et al. 1996), whilst phosphorylation of serine 167 (S167) in AF-1 by AKT and p90RSK also stimulates ER $\alpha$ activity (Joel $e t a l$. 1998a, Campbell $e t$ al. 2001). The ER $\alpha$ AF-1 is additionally phosphorylated at serines 104 (S104) and/or 106 (S106) (Le Goff et al. 1994). Phosphorylation at these sites by Cdk2 (Trowbridge et al. 1997, Rogatsky et al. 1999) and GSK3 (Medunjanin et al. 2005) has been reported, and our own data have previously indicated that these sites might also be targets for MAPK (Chen et al. 2002). Increased $\mathrm{ER} \alpha$ activity due to AF-1 phosphorylation mediated by MAPK and/or other kinases could therefore be at least partly responsible for resistance to endocrine therapy in breast cancer. This hypothesis is supported by findings that stimulation of growth factor-regulated pathways can augment the agonist properties of tamoxifen (Smith 1998) and inhibit tamoxifen-induced growth suppression and apoptosis in breast cancer cells (Benz et al. 1993, Pietras et al. 1995, Campbell et al. 2001). Here, we investigate phosphorylation at serines 104 and 106 by Erk2 MAPK in vitro and in response to MAPK activity in vivo, and determine their contribution to ER $\alpha$ activity. Transcription reporter assays using ER $\alpha$ phosphorylation site mutants suggest that phosphorylation at all three sites contribute significantly to AF-1 activity, and in particular are required for tamoxifen to act as an ER $\alpha$ agonist.

\section{Materials and methods}

\section{Plasmids}

The expression vectors pSG5-HEG0 and pSG5-HE15, encoding full length and AF-2-truncated human ER $\alpha$ (ER $\alpha-\Delta \mathrm{LBD})$ respectively have previously been described

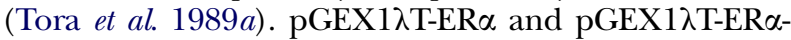
$\Delta \mathrm{LBD}$ were generated by cloning ER $\alpha$ encoding EcoRI fragments from pSG5 into pGEX1 $\lambda$ T (GE Healthcare UK Ltd, Little Chalfont, UK). ER $\alpha$ mutants were generated by site-directed mutagenesis, according to manufacturer's protocols (Stratagene, La Jolla, CA, USA). pEF-RasV12, expression vector for constitutively active Ha-Ras, was kindly provided by Dr R Treisman (LRI, London, UK). pCMV-Raf CAAX and pCMV-Raf S621A were purchased from Clontech (Saint-Germaine-en-Laye, France).

\section{Antibodies}

Peptides corresponding to amino acids 97-112 of human $\mathrm{ER} \alpha$, having the sequence [C]-FPPLNSV ${ }^{\mathrm{P}}$ SPSPLMLLH (phospho-S104) or [C]-FPPLNSVSP ${ }^{\mathrm{P}}$ SPLMLLH (phospho-S106), were used to generate rabbit polyclonal antisera, as described (Chen et al. 2002). Antibodies specific for $\mathrm{ER} \alpha$ phosphorylated at S118 (16J4, New England Biolabs, Hitchin, UK), ER $\alpha$ (6F11, Novocastra Laboratories, UK), MAPK (sc-93, Santa Cruz Biotechnology, Heidelberg, Germany) and P-MAPK (New England Biolabs) were obtained commercially. Horseradish peroxidase-conjugated goat anti-rabbit and anti-mouse immunoglobulins were purchased from DAKO Ltd, Ely, UK.

\section{Immunoblot analysis}

Cells were grown in Dulbecco's modified Eagle's medium (DMEM) lacking phenol red and supplemented with $10 \%$ dextran-coated charcoal-stripped fetal calf serum (DSS) for 3 days prior to plating in six-well plates at 300000 cells/well. Cells were transfected using Fugene 6 (Millipore, Wafford, UK), with $100 \mathrm{ng}$ pSG5 empty vector or ER $\alpha$ expression construct, $5 \mathrm{ng}$ empty vector or Ras/Raf expression construct, and $500 \mathrm{ng}$ pBS+ carrier DNA, as appropriate. After $48 \mathrm{~h}$ the cells were treated with ethanol carrier, estradiol $\left(\mathrm{E}_{2} ; 10 \mathrm{nM}\right)$, 4-hydroxytamoxifen (OHT; $100 \mathrm{nM}$ ) or ICI182,780 (ICI; $100 \mathrm{nM}) 30 \mathrm{~min}$ prior to harvest, phorbol 12myristate 13 acetate (PMA; $100 \mathrm{nM}$ ) was added $15 \mathrm{~min}$, and U0126 $(10 \mu \mathrm{M})$ was added $60 \mathrm{~min}$, prior to harvesting, as appropriate. Cells were washed and harvested 
directly into Laemmli buffer and immunoblotting was performed, as described (Sarwar et al. 2006). For peptide competition experiments, the primary antibodies were pre-incubated with $10 \mu \mathrm{g} / \mathrm{ml}$ of the appropriate peptide (Chen et al. 2002). Quantitation of phospho-ER $\alpha$ signal was performed by densitometry of scanned films using ImageQuant software, and expressed relative to the respective total ER level.

\section{Kinase assays}

The glutathione-S-transferase (GST) fusion proteins, GST-ER $\alpha$ and GST-ER $\alpha-\Delta$ LBD were expressed in Escherichia coli (Rosetta strain, Merck Chemicals Ltd, Nottingham, UK) following induction with $0.1 \mathrm{mM}$ isopropyl-beta-D-thiogalactopyranoside (IPTG) for $3 \mathrm{~h}$ at $25^{\circ} \mathrm{C}$. Cells $(50 \mathrm{ml})$ were lysed with $10 \mathrm{ml}$ XTractor buffer (BD Biosciences, Oxford, UK) containing $1 \mathrm{mM}$ dithiothreitol (DTT) and protease inhibitors, and the lysates cleared by high-speed centrifugation. The lysates were incubated with glutathione-sepharose beads at $4^{\circ} \mathrm{C}$ for $1 \mathrm{~h}$, and the beads were washed thrice with TBS containing $1 \mathrm{mM}$ DTT and protease inhibitors. GST-ER $\alpha$ beads were resuspended in $1 \times$ kinase buffer, $200 \mu \mathrm{M}$ ATP, $\pm \mathrm{E}_{2}(10 \mathrm{nM})$ and kinase (Erk2 and GSK3, New England Biolabs, UK; Cdk2/cyclin A, Cdk2/cyclin E, Cdk4/cyclin D1, Cdk7/cyclin H/MAT1, AKT1, and AKT3; New England Biolabs), according to manufacturer's instructions. For radioactive kinase assays, $50 \mu \mathrm{M}$ cold ATP and $10 \mu \mathrm{M}{ }^{32} \mathrm{P} \gamma \mathrm{ATP}$ (Amersham) was used. Reactions were incubated at $30{ }^{\circ} \mathrm{C}$ for $30 \mathrm{~min}$ and processed by SDS-PAGE followed by autoradiography or immunoblot.

\section{Reporter assays}

Cells were grown in DMEM lacking phenol red and supplemented with $10 \%$ DSS for 3 days prior to plating in 24-well plates at 50000 cells/well. Cells were transfected using Fugene 6 (Roche), with $100 \mathrm{ng}$ pERE3-TATA-luc and pRL-TK reporters, $10 \mathrm{ng}$ pSG5 empty vector or ER $\alpha$ expression construct, $50 \mathrm{ng}$ empty vector or Ras/Raf expression vector, and $500 \mathrm{ng} \mathrm{pBS}+$ carrier DNA. After $4 \mathrm{~h}$, the medium was replaced with fresh media containing ethanol carrier, $\mathrm{E}_{2}$, OHT or ICI 182780 , at concentrations indicated in figures. After a further $20 \mathrm{~h}$, the cells were harvested and luciferase levels determined using Dual-Glo reagents (Promega). For experiments in which U0126 was used, $10 \mathrm{nM} \mathrm{U} 0126$ was added $1 \mathrm{~h}$ prior to the addition of ligands and the cells were harvested after a further $7 \mathrm{~h}$. Firefly luciferase levels were corrected for transfection efficiency using corresponding renilla luciferase levels. The activity for wild-type ER $\alpha$ in the absence of ligand was taken as one, with all other activities shown relative to this. All experiments were independently repeated at least four times, and the data presented as mean values with s.E.M. error bars.

\section{Results}

\section{Antisera display specificity for ER $\alpha$ phosphorylated at $\mathrm{S} 104$ and $\mathrm{S} 106$}

Serines 104 and/or 106 have been shown to be phosphorylated by Cdk2/cyclin A and Cdk2/cyclin E (Trowbridge et al. 1997, Rogatsky et al. 1999), and GSK3 (Medunjanin et al. 2005). To further characterize ER $\alpha$ phosphorylation at these residues, we generated rabbit antisera specific for phosphorylation at S104 ( $\alpha$-PS104) or at S106 ( $\alpha$-PS106). S104 phosphorylation was stimulated following treatment of ER $\alpha$-transfected COS-1 cells with $\mathrm{E}_{2}$ and PMA (Fig. 1A). ER $\alpha$ mutants in which S104 was substituted by alanine were not detected by $\alpha$-PS104, whilst mutation of S106 (106A) reduced but did not abolish S104 phosphorylation. S106 phosphorylation was also stimulated by $\mathrm{E}_{2}$ and PMA, and blocked by mutants of S106 but not S104. Competition with phosphorylated peptides further confirmed that $\alpha$-PS104 and $\alpha$-PS106 are specific for $\mathrm{ER} \alpha$ phosphorylated at S104 and S106 respectively. Detection of phopho-S104 ER $\alpha$ and phospho-S106 $\mathrm{ER} \alpha$ were blocked by pre-incubation of the respective antiserum with a 100-fold excess of peptides containing a phosphorylated S104 (PS104 and PS104/6), and phosphorylated S106 (PS106 and PS104/6) respectively.

Investigation of phosphorylation using mutants in which S104, S106, and S118 were substituted by alanine or glutamic acid, either singly or together, showed that S104 phosphorylation was influenced by the status of S106 and S118 (Fig. 1B). This result could potentially be explained by a reduced efficacy of $\alpha$-PS104 binding when S106 or S118 are not phosphorylated, but this is not supported by the fact that $\alpha$-PS104 binding was competed similarly by both the PS104 and PS104/6 peptides (Fig. 1A). Hence, phosphorylation at S106 and S118 may be important for subsequent phosphorylation of S104. S106 phosphorylation was lower in the case of S118A, but not S104A, suggesting a role for S118 in S106 phosphorylation. In the case of S118, the data suggest that S104, but not S106 influences S118 phosphorylation. Together, these findings are indicative of crosstalk between S104, S106, and S118, which regulates phosphorylation at these sites.

\section{Phosphorylation at S104 and S106 is induced by ER $\alpha$ ligands and PMA, and by activated Raf/Ras}

S118 phosphorylation is stimulated by $\mathrm{E}_{2}$, as well as antiestrogens (Joel et al. 1995, 1998b) and can be mediated 


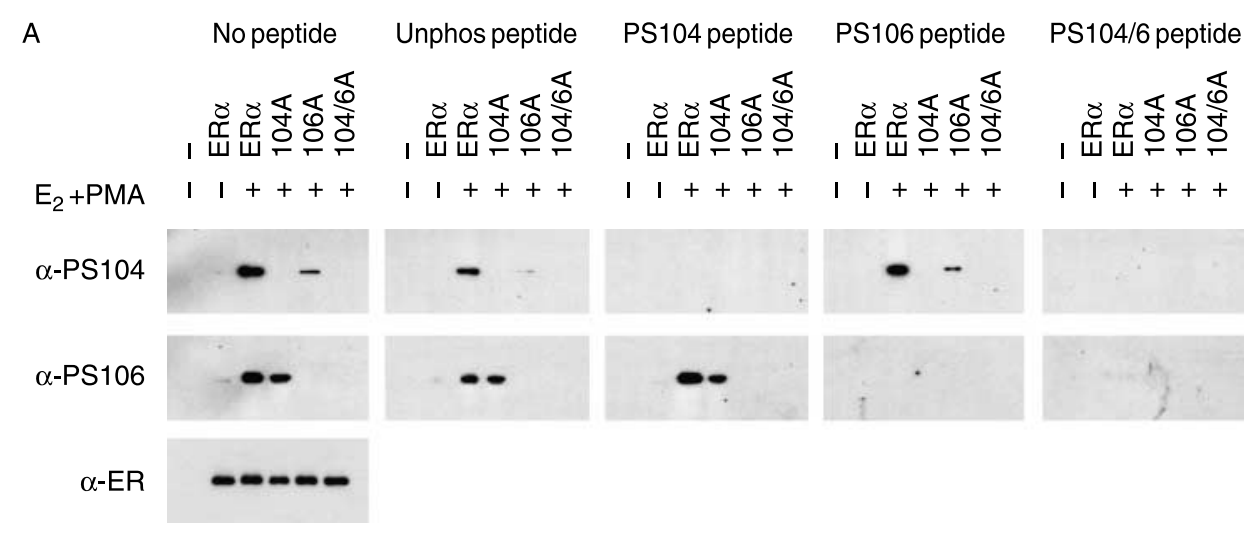

B

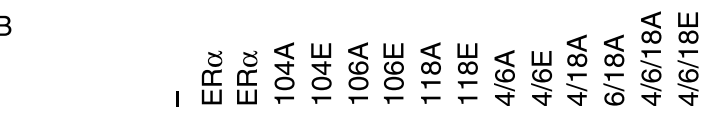

$\mathrm{E}_{2}+\mathrm{PMA}--+++++++++++++$

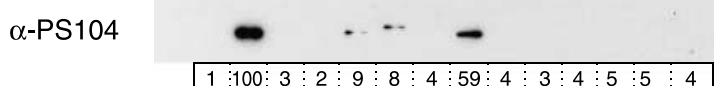

$\alpha-P S 106$

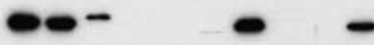

$2 \vdots 100 \vdots 119: 36 \vdots 1 \vdots 1 \vdots 3 \vdots 105 \vdots 3 \vdots 1 \vdots 95 \vdots 4 \vdots 2 \vdots 2$

$\alpha-\mathrm{PS} 118$

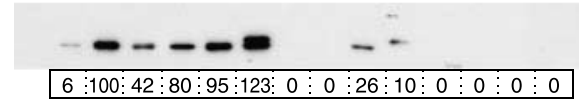

$\alpha-E R$

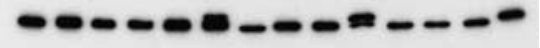

Figure 1 Characterization of phospho-specific antisera by peptide competition and phosphorylation site substitutions. Lysates prepared from COS-1 cells transiently transfected with an empty expression vector $(-)$, or expression vectors for wild-type $\mathrm{ER} \alpha$ or $\mathrm{ER} \alpha$ in which $\mathrm{S104}, \mathrm{S} 106$, and/or S118 had been substituted by alanine (A) or glutamic acid (E), as indicated, were immunoblotted using antibodies for total $E R \alpha(\alpha-E R)$, or for ER $\alpha$ phosphorylated at S104 ( $\alpha$-PS104) or S106 ( $\alpha$-PS106). Cells were treated with ethanol solvent $(-)$, or $17 \beta$-estradiol $\left(E_{2} ; 10 \mathrm{nM}\right)$ and 12-tetradecanoylphorbol-13-acetate (PMA; $\left.100 \mathrm{nM}\right)$, for 30 min prior to harvesting. (A) Replicate blots were incubated with primary antibody (no peptide), or antibody that had been pre-incubated with a 100 -fold excess $(10 \mu \mathrm{g} / \mathrm{ml})$ of a peptide encompassing the ER $\alpha$ phosphorylation site; either unphosphorylated (unphos) or phosphorylated (PS104, PS106, or dual PS104/6) versions, as indicated. (B) Lysates were additionally immunoblotted using antibody for ER $\alpha$ phosphorylated at $\mathrm{S} 118$ $(\alpha-P S 118)$. Levels of phospho-ER $\alpha$ were quantitated in relation to the respective total ER $\alpha$ level (boxed, below each immunoblot).

by Cdk7 (Chen et al. 2000, 2002). Further, S118 can be phosphorylated by MAPK in response to EGF and PMA (Kato et al. 1995, Bunone et al. 1996, Chen et al. 2002). Phosphorylation of S104 and S106 was also stimulated by $\mathrm{E}_{2}$, OHT, ICI, and PMA (Fig. 2A). In the case of PMA, this phosphorylation was decreased by the MEK1/2 inhibitor U0126, and corresponds to a decrease in activated Erk1/2 MAPK. The phosphorylation induced by ligands was mostly unaffected by the addition of U0126, except that of $\mathrm{S104}$ in response to OHT and ICI, which were reduced. Co-expression of $\mathrm{ER} \alpha$ with constitutively active Ha-Ras (Ras-V12) or Raf1
(Raf-CAAX) resulted in enhanced phosphorylation of S104, S106, and S118, whereas the kinase-dead mutant of Raf1 (Raf-S621A) did not (Fig. 2B). Together, these data indicate that S104, S106, and S118 can be phosphorylated by Erk1/2 MAPK in response to activation of the upstream pathways, and also though MAPK-independent pathways upon ligand binding.

In agreement with the above findings, purified Erk2 readily phosphorylated GST-ER $\alpha$ at S104, S106, and S118 (Fig. 3A). Cdk2 also phosphorylated S104 and S118, but did not appear to phosphorylate S106. GSK3 also phosphorylated S104, with longer 
A
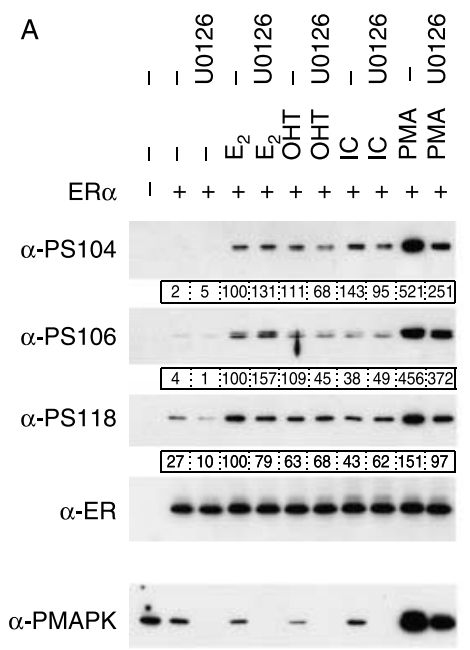

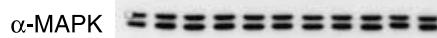

B

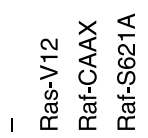

$\mathrm{ER} \alpha$
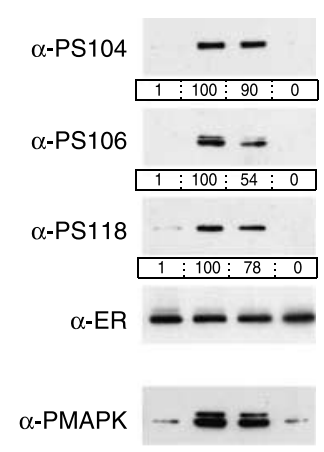

$\alpha-M A P K$

\section{S104, S106, and S118 are important for ER $\alpha$ activity}

In reporter gene assays, substitution of S104, S106, and S118 by alanine $(4 / 6 / 18 \mathrm{~A})$ resulted in a reduction in $\mathrm{ER} \alpha$ activity in the presence of $\mathrm{E}_{2}$ by nearly $50 \%$, whilst substitution with glutamic or aspartic acid, to 'mimic' phosphorylation at these sites, stimulated ER $\alpha$ activity two- to threefold (Fig. 4A). ER $\alpha$ activity for the alanine mutant in the presence of OHT was reduced by $>80 \%$, and was two- to threefold higher for the $4 / 6 / 18 \mathrm{E}$ and 4/6/18D mutants. Significant ER $\alpha$ activation (sevenfold relative to wild-type $\mathrm{ER} \alpha$ ) was also observed in the absence of ligand for $4 / 6 / 18 \mathrm{E}$ and $4 / 6 / 18 \mathrm{D}$. These data suggest that phosphorylation at one or more of these residues is critical for AF- 1 activity and for the agonist activity of OHT. Western analysis of total ER $\alpha$ levels indicated relatively equal levels of expression across the mutants and across different ligand treatments. ICI is generally thought to decrease ER $\alpha$ levels, but in many cases a change in solubility is mistaken for degradation (Lipfert et al. 2005); the assays here have measured total ER $\alpha$ levels.

To examine whether acidic substitutions in ER $\alpha$ resulted in ligand hypersensitivity, we examined ER $\alpha$ activity by reporter assay in the presence of increasing concentrations of estrogen and OHT (Fig. 4B). The acidic $\mathrm{ER} \alpha$ mutant displayed an enhanced activity, of similar magnitude compared with wild-type $\mathrm{ER} \alpha$, at all ligand concentrations. Hence, although the acidic mutant could yield equivalent levels of activity at lower ligand concentrations compared with that of wild-type $\mathrm{ER} \alpha$ at higher ligand concentrations (compare $4 / 6 / 18 \mathrm{E}$ at $0 \cdot 1 \mathrm{nM} \mathrm{E} \mathrm{E}_{2}$ with wt at $1 \mathrm{nM} \mathrm{E}$, and $4 / 6 / 18 \mathrm{E}$ at $1 \mathrm{mM} \mathrm{OHT}$ with wt at $100 \mathrm{mM} \mathrm{OHT}$ ), there was no evidence for enhanced ligand sensitivity.

$\mathrm{ER} \alpha \mathrm{AF}-1$ is only weakly active in HeLa cells, with the majority of $\mathrm{ER} \alpha$ activity in HeLa cells being due to AF-2 (Bocquel et al. 1989). Further, the lack of AF-1 activity correlates with lack of agonist activity for OHT in HeLa cells (Bocquel et al. 1989, Berry et al. 1990). Triple acidic substitution stimulated ER $\alpha$ activity in the absence of ligand, as well as in the presence of $\mathrm{E}_{2}$ (Fig. 4C). Activity in the presence of OHT was also increased, but was not significantly greater than that obtained in the absence of ligand. Hence, acidic substitutions in AF-1 enhanced $\mathrm{ER} \alpha$ activity in HeLa cells in a similar manner to COS-1 cells, but did not activate an OHT response. Finally, in the estrogen responsive and ER $\alpha$-positive MCF7 breast cancer cell line, transfection of ER $\alpha$ stimulated reporter gene activity over and above the activity observed for endogenous ER $\alpha$ (Fig. 4D). Reporter gene activity for the glutamic and aspartic acid mutants was significantly greater in the absence of ligand or in the presence of $\mathrm{E}_{2}$ or OHT, compared with the activities obtained for wild-type $\mathrm{ER} \alpha$, generally following what was seen using COS-1 cells. 
A

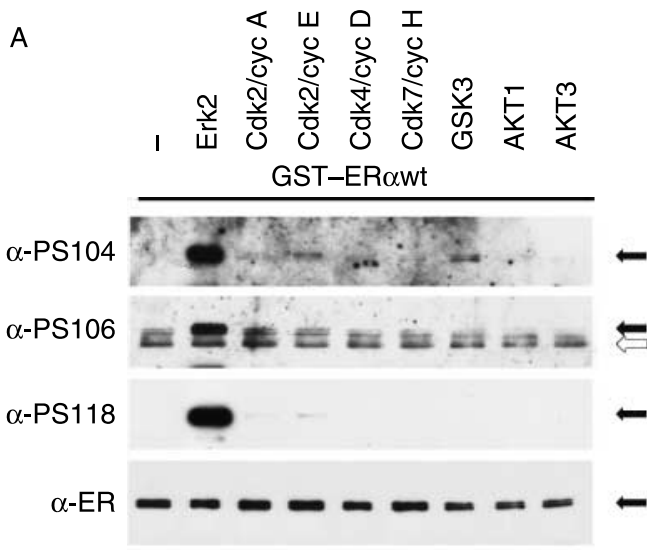

B
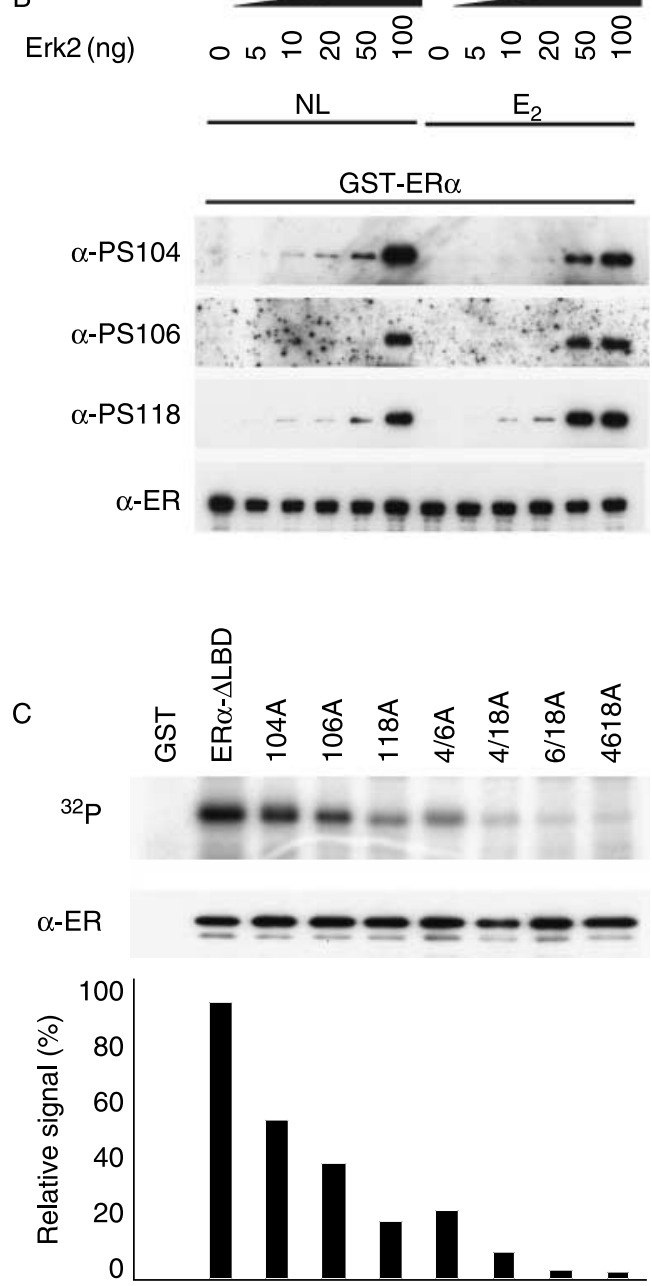

Phosphorylation at S104, S106, and S118 contributes to ER $\alpha$ activity

The above data demonstrate that serines 104, 106, and 118 are critical for AF-1 activity, and likely for AF-1 cooperativity with AF-2. In order to define the relative importance of these sites, single and double mutants were examined for their effect on $\mathrm{ER} \alpha$ activity (Fig. 5). Substitution of S118 by alanine reduced OHT-stimulated $\mathrm{ER} \alpha$ activity. Alanine substitution of $104 \mathrm{~A}$ or 106A had little effect on OHT stimulation of ER $\alpha$, although $\mathrm{ER} \alpha-104 \mathrm{~A} / 106 \mathrm{~A}$ was significantly less active than wild-type $\mathrm{ER} \alpha$. Interestingly, S104 or S106 mutations together with mutation of $\mathrm{S} 118$ reduced $\mathrm{ER} \alpha$ activity more potently than the S118 substitution alone. On the basis of these findings, the order of importance of the three serines appears to be S118> S104 $>$ S106. Although mutation of S106 to alanine had very little effect on $\mathrm{ER} \alpha$ activity, its substitution by glutamic acid resulted in the greatest stimulation in ER $\alpha$ activity, with the order of activity for the three mutants being $\mathrm{S} 106>\mathrm{S} 104>\mathrm{S} 118$, opposite to the relative activities observed with the alanine substitutions. Nevertheless, in agreement with the findings from the alanine mutants, multiple substitutions increased ER $\alpha$ activity correspondingly, again suggesting that all three phosphorylation sites are important for AF-1 activity.

\section{Activated Ras/Raf enhances ER $\alpha$ activity}

In order to confirm the role of MAPK in the phosphorylation of S104 and S106, NIH-3T3 cells were co-transfected with reporter constructs and $\mathrm{ER} \alpha$, together with expression vectors encoding Ras or Raf (Fig. 6A). ER $\alpha$ activity was significantly enhanced by constitutively active Ha-Ras (Ras-V12) and Raf1 (RafCAAX), and was inhibited by a kinase-dead mutant of Raf1 (Raf-S621A). By contrast, ER $\alpha-104 \mathrm{~A} / 106 \mathrm{~A} / 118 \mathrm{~A}$ activity was not stimulated by Ras-V12 or Raf-CAAX. U0126 did not significantly inhibit the activities of

Figure 3 S104 and S106 are phosphorylated by Erk2 in vitro. (A) Purified GST-ER $\alpha$ was incubated with a panel of purified kinases, as indicated, according to manufacturer's instructions, followed by immunoblotting with phospho-specific antibodies $(\alpha$-PS104, $\alpha$-PS106, and $\alpha$-PS118) or $\alpha$-ER. The filled arrows indicate the position of GST-ER $\alpha$, and the open arrow indicates a non-specific product seen with $\alpha$-PS106 antisera. (B) Purified GST-ER $\alpha$ was incubated with increasing amounts of purified Erk2 $\operatorname{MAPK}(0,5,10,20,50$, and $100 \mathrm{ng})$ in the absence of ligand (NL) or in the presence of $E_{2}(10 \mathrm{nM})$, followed by immunoblotting as before. (C) Purified GST, or wild-type GS $\alpha$ T-ER $\alpha-\Delta$ LBD

$(E R \alpha-\Delta L B D)$ or GST-ER $\alpha-\Delta$ LBD in which S104, S106, and/or $S 118$ had been substituted by alanine $(A)$, as indicated, were incubated with Erk2 in the presence of ${ }^{32} \mathrm{P}-\gamma$ ATP, followed by SDS-PAGE and autoradiography of the dried gel. Immunoblotting a duplicate gel with $\alpha$-ER was used to determine the relative levels of each mutant. The bar chart shows quantification of each ${ }^{32} \mathrm{P}$ signal relative to the respective total GST-ER $\alpha-\Delta$ LBD level. 

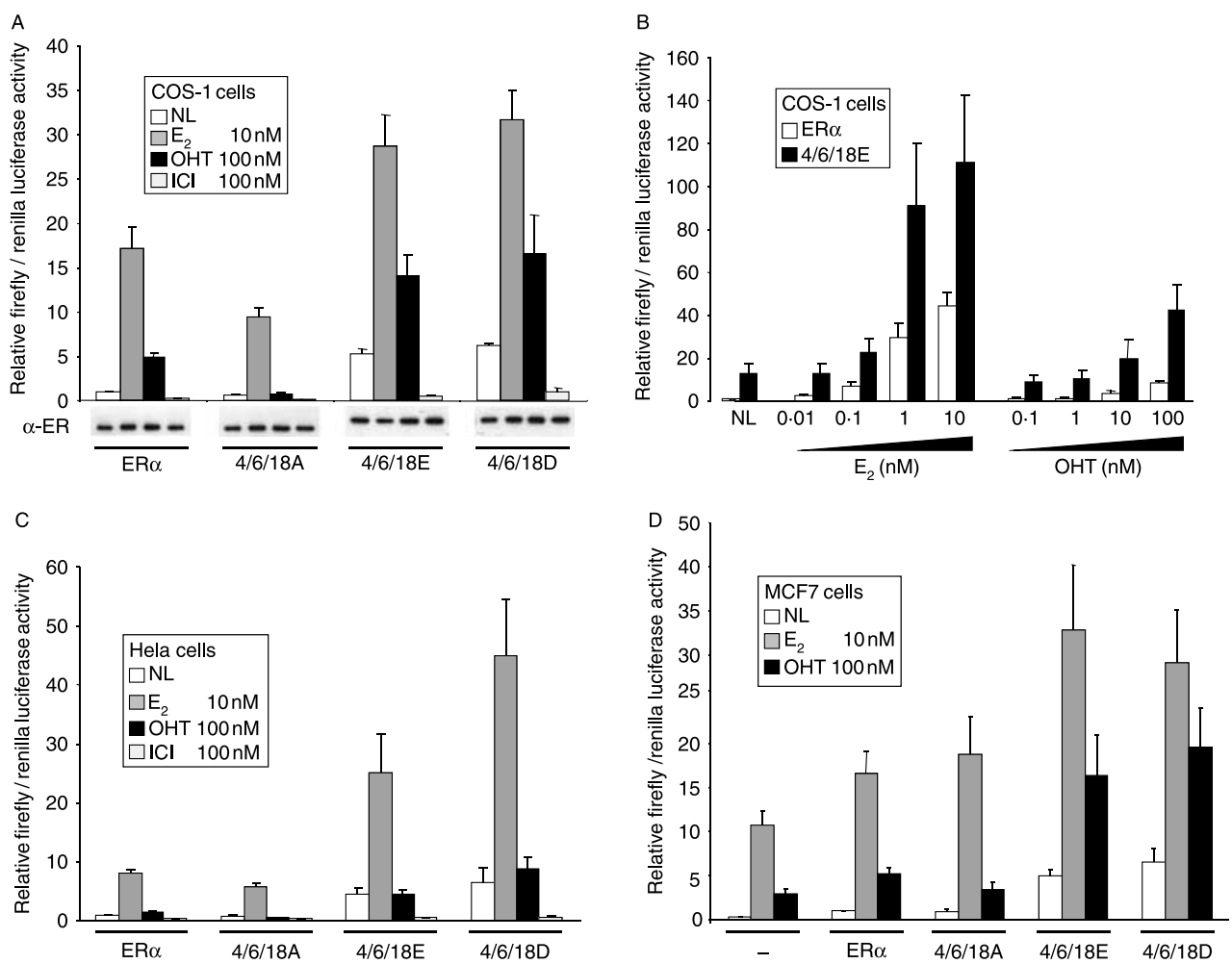

Figure 4 Effect of phosphorylation site mutations on ER $\alpha$ activity. (A and B) COS-1, (C) HeLa, and (D) MCF7 cells were co-transfected with the ERE-3-TATA-firefly luciferase reporter gene, a renilla luciferase control reporter gene, and expression vectors encoding wild-type $\mathrm{ER} \alpha(\mathrm{ER} \alpha)$ or $\mathrm{ER} \alpha$ in which $\mathrm{S} 104, \mathrm{~S} 106$ and S118 were substituted by alanine (4/6/18A), glutamic acid (4/6/18E) or aspartic acid (4/6/18D), as indicated. Cells were treated with ethanol solvent (no ligand; NL), $E_{2}(10 \mathrm{nM}), \mathrm{OHT}(100 \mathrm{nM})$ or ICl $(100 \mathrm{nM})$, as indicated, except $(\mathrm{B})$ where $\mathrm{E}_{2}$ was added at $0 \cdot 01,0 \cdot 1,1$, and $10 \mathrm{nM}$ and OHT at $0 \cdot 1,1,10$, or $100 \mathrm{nM}$. The cells were harvested for luciferase assays $20 \mathrm{~h}$ later. Results are presented as relative ratios of firefly to renilla control luciferase activities, as described in Materials and methods. (A) A parallel transfection series was assayed for ER $\alpha$ expression by immunoblot $(\alpha-E R)$. (D) MCF7 cells were additionally transfected with an empty vector control $(-)$ in order to determine the contribution of endogenous $\mathrm{ER} \alpha$.

$\mathrm{ER} \alpha-104 \mathrm{~A} / 106 \mathrm{~A} / 118 \mathrm{~A}$ or $104 \mathrm{E} / 106 \mathrm{E} / 118 \mathrm{E}$, but did inhibit the activities of wt $\mathrm{ER} \alpha$ and those encoding individual alanine mutants (Fig. 6B). Similar results were obtained by treatment with another MEK1/2 inhibitor, PD98059 (data not shown). These data suggest that the activation of the Ras/Raf/MEK/ MAPK signal transduction pathway results in ER $\alpha$ activation through phosphorylation at S104, S106, and S118.

\section{Discussion}

Phosphorylation at serine 118 in the AF-1 domain of $\mathrm{ER} \alpha$ has been demonstrated by us and other researchers to be important for ER $\alpha$ activity (Ali et al. 1993, Le Goff et al. 1994, Kato et al. 1995, Bunone et al. 1996, Chen et al. 2000, 2002). Phosphorylation of serines 104 and 106 has also been shown to augment $\mathrm{ER} \alpha$ activity (Le Goff et al. 1994), but their phosphorylation and function have not been investigated thoroughly.

In order to investigate phosphorylation of these residues in greater detail, we generated phosphorylation sitespecific antisera. The antisera demonstrated appropriate specificity for ER $\alpha$ phosphorylated at S104 or S106, determined using multiple point mutants of S104 and S106 and peptide competition of antibody binding, and confirms that both S104 and S106 of ER $\alpha$ can be phosphorylated. Interestingly, phosphorylation at S104 appeared to be substantially reduced by substitutions at S106 and S118, and S106 phosphorylation reduced by S104E and S118A. S118 phosphorylation was also somewhat reduced by $\mathrm{S} 104$ substitutions. The epitopes for the $\alpha$-PS104 and $\alpha$-PS106 antisera may overlap, but the peptide competition studies of antibody specificity go some way to suggest that these antisera are not influenced by the 


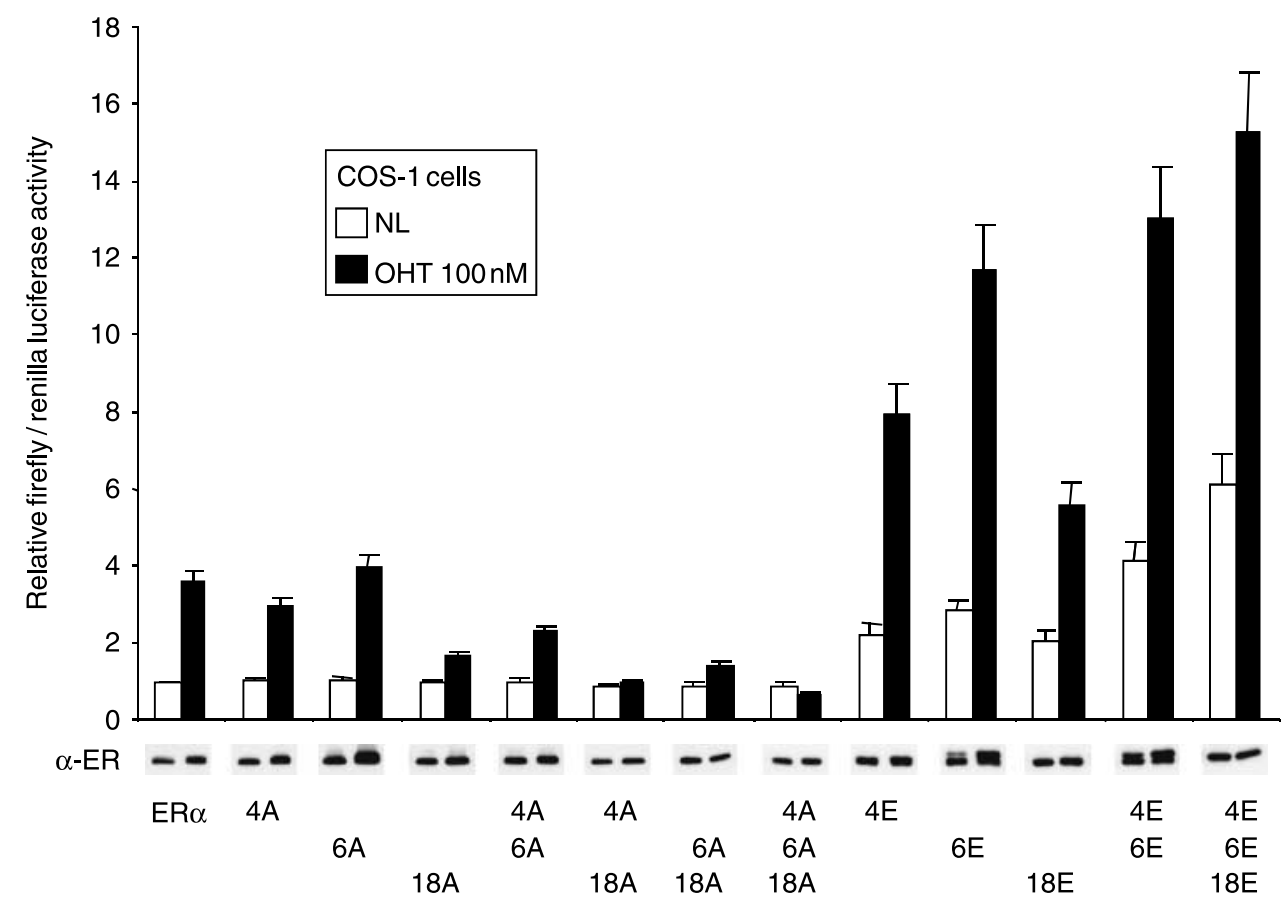

Figure 5 Effect of individual site mutations on ER $\alpha$ activity. COS- 1 cells were co-transfected with ERE-3TATA-luc, pRL-TK, and the wild-type ER $\alpha$ expression vector $(E R \alpha)$ or versions with alanine or glutamic acid substitutions, as indicated. Cells were treated and luciferase assays carried out as for Fig. 4. A parallel transfection series was assayed for $\mathrm{ER} \alpha$ expression by immunoblot $(\alpha-\mathrm{ER})$.

phosphorylation status at the respective adjacent site. Thus, in general, phosphorylation at these sites appears to be partly interdependent. We cannot, of course, rule out the possibility that these substitutions simply affect an ER $\alpha$ conformation required for efficient phosphorylation.

Previous studies have indicated that the agonist activity of tamoxifen (OHT) is due to activation of AF-1, whilst AF-2 function is inhibited (Tora et al. 1989b, Berry et al. 1990). In reporter gene assays using OHT, alanine substitution of S104, S106, or S118 inhibited ER $\alpha$ activity, with the greatest inhibition being observed with substitution of all three residues. Similarly, substitution of the individual sites by glutamic acid augmented ER $\alpha$ activity, with the greatest activity being seen for the triple mutant. Additionally, these sites appear to be important for estrogen-induced and ligandindependent $\mathrm{ER} \alpha$ activities. These data suggest that phosphorylation at some or all three sites is critical for AF-1 activity and for the agonist action of OHT. Substitution of S118 to alanine resulted in a greater loss of function compared with that of S104 and S106, but glutamic acid substitutions suggested that achieving a high level of phosphorylation at S104 and S106 might have a greater impact upon ER $\alpha$ function than that at S118. These apparently contradictory results may be explained by functionally stronger S104 and S106 sites being phosphorylated at lower levels in COS-1 cells, relative to that at $\mathrm{S} 118$. It is additionally difficult to assign levels of importance to these sites, since immunoblot analysis of ER $\alpha$ substitution mutants suggested that S104, S106, and S118 phosphorylation is partly interdependent. Our data instead suggest that these three sites, together, comprise a complex phosphorylated domain, involved in augmenting ER $\alpha$ activity.

Reporter gene assays indicated that the activity of the $\mathrm{ER} \alpha-4 / 6 / 18 \mathrm{E}$ mutant (and 4/6/18D mutant) in the absence of ligand was at a level similar to that seen for wildtype ER $\alpha$ in the presence of OHT, suggesting that OHTinduced phosphorylation at these residues may be sufficient for AF-1 activity. However, the further stimulation of $\mathrm{ER} \alpha-4 / 6 / 18 \mathrm{E}$ activity by tamoxifen in COS- 1 cells, suggests that the agonist activity of OHT is not solely due to stimulation of phosphorylation at these sites. Indeed, acidic substitutions did not lead to a restoration of OHT-induced ER $\alpha$ activity in HeLa cells, in which ER $\alpha$ AF-1 activity is known to be low and associated with little or no stimulation by OHT (Tora et al. 1989b, Berry et al. 1990). These data further support the view that the agonist activity of OHT is not due simply to stimulation of AF-1 phosphorylation. Thus, although OHT agonist activity is dependent upon (and induces) phosphorylation, other factors - possibly cell context-dependent expression of coactivators and corepressors (Shang \& Brown 2002) - are also likely to be involved.

Previous reports have shown that Cdk2 (Trowbridge et al. 1997, Rogatsky et al. 1999) and GSK3 (Medunjanin 

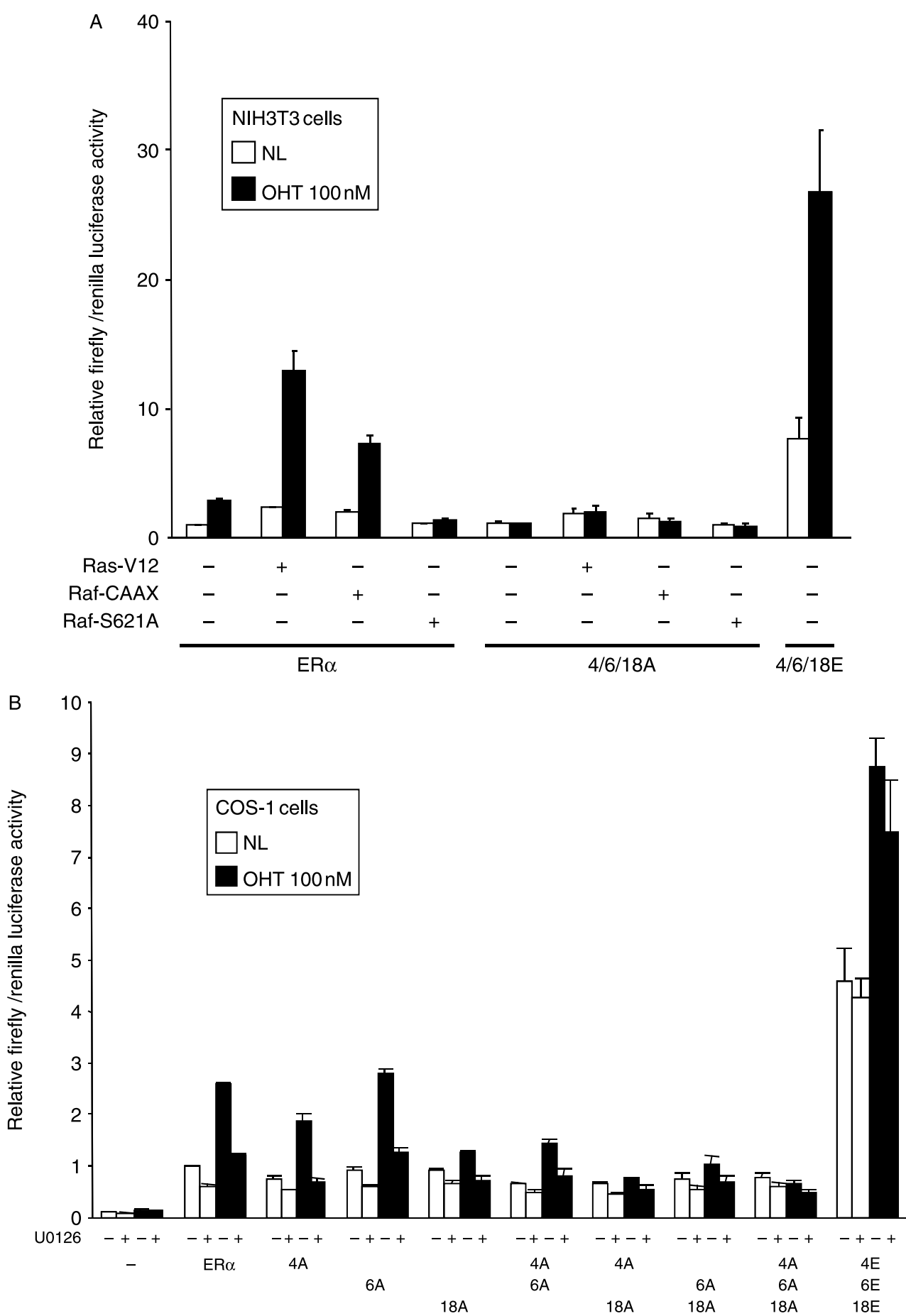

Figure 6 Effect of MAPK signaling activators and inhibitors on ER $\alpha$ activity. (A) NIH3T3 cells were co-transfected with ERE-3-TATA-luc, pRL-TK, and the wild-type ER $\alpha$ expression vector (ER $\alpha$ ), or versions in which S104, S106, and S118 were substituted by alanine $(4 / 6 / 18 \mathrm{~A})$ or glutamic acid $(4 / 6 / 18 \mathrm{E})$, as indicated. Cells were additionally co-transfected with empty expression vector $(-)$ or expression vectors for Ras-V12, Raf-CAAX, or Raf-S621A, as shown. Cells were treated and luciferase assays carried out as for Fig. 4. (B) COS-1 cells were transfected with ERE-3-TATA-luc, pRL-TK, and the wildtype $E R \alpha$ expression vector $(E R \alpha)$ or versions with alanine or glutamic acid substitutions, as indicated. Cells were pre-incubated with U0126 $(10 \mu \mathrm{M}), 16 \mathrm{~h}$ following transfection, as indicated, for $1 \mathrm{~h}$ prior to addition of $\mathrm{OHT}$, and harvested for luciferase assays $7 \mathrm{~h}$ later. 
et al. 2005) can phosphorylate S104 and/or S106. However, whilst investigating the phosphorylation of S118, we had previously observed that mutation of S104 and $\mathrm{S} 106$ reduced the levels of $\mathrm{ER} \alpha$ phosphorylation by MAPK in vitro (Chen et al. 2002). In agreement with this, we show here that S104 and S106 phosphorylation was stimulated by PMA and inhibited by the MEK1/2 inhibitor U0126, in transfected COS-1 cells. Further, co-transfection with activated Ras-V12 or Raf-CAAX, but not dominant-negative Raf-S621A, stimulated S104 and S106 phosphorylation. Together, these results suggest that serines 104 and 106 are phosphorylated by Erk1/2 MAPK. In vitro kinase experiments confirmed that, in addition to phosphorylating S118, Erk2 could also directly phosphorylate S104 and S106. Of the other kinases tested, Cdk2 was able to phosphorylate S104 and S118, and GSK3 able to phosphorylate S104, but to levels considerably lower than that achieved by Erk2. However, Cdk2 and/or GSK3 may phosphorylate S104 and/or S106 in vivo. Indeed, ligand-stimulated phosphorylation was in most cases insensitive to U0126, suggesting the involvement of other kinases. However, OHT- and ICI-induced phosphorylation of S104 did appear to partly involve MAPK, raising the possibility that multiple kinases are differentially involved, depending on the specific ligand.

In reporter gene assays, constitutively active Ras and Raf stimulated $\mathrm{ER} \alpha$ activity in the absence of ligand or in the presence of OHT. Substitution of S104/S106/S118 by alanine prevented $\mathrm{ER} \alpha$ activation by $\mathrm{Ras}$ and Raf, indicating that these sites are required for MAPK stimulation of ER $\alpha$ activity. Furthermore, U0126 inhibited $\mathrm{ER} \alpha$ activity, as did dominant-negative Raf, but had little effect on triple S104, S106, and S118 mutants. These results suggest that the inhibitory effect of Raf-S621A and U0126 on $\mathrm{ER} \alpha$ activity was due to the inhibition of phosphorylation at some or all of the three sites, and further implicates MAPK in the phosphorylation of S104, S106, and S118. Phosphorylation of S104, S106, and S118 could also be induced by ER $\alpha$ ligands; $\mathrm{E}_{2}$, OHT, and ICI in COS-1 cells. The in vitro kinase assays indicated that ligand-binding results in marginally more efficient phosphorylation of ER $\alpha$ by MAPK, perhaps due to the altered conformation of $\mathrm{ER} \alpha$ and/or unmasking of potential MAPK docking site(s) (Obenauer et al. 2003). However, ligand-stimulated phosphorylation of ER $\alpha$ in vivo was largely insensitive to U0126, and may be mediated by Cdk2 and/or GSK3 (Trowbridge et al. 1997, Rogatsky et al. 1999, Medunjanin et al. 2005).

In conclusion, phosphorylation of S104, S106, and $\mathrm{S} 118$ is important for ER $\alpha \mathrm{AF}-1$ activity, as displayed by enhanced ligand-independent, and $\mathrm{E}_{2}$ - and OHT-dependent, activities. This enhanced activity is not due to ligand hypersensitivity. No one site is critical, but lack of phosphorylation at all of the sites together results in near complete loss of AF-1 activity and prevents the agonist action of OHT. Additionally, phosphorylation of these sites occurs in a partially interdependent manner and phosphorylation at each site appears to act via a similar mechanism to enhance ER $\alpha$ activity, suggesting that this region constitutes a phospho-regulated domain of cooperative MAPK phosphorylation sites. Activation of the EGF receptor and ErbB2 pathways, which signal through MAPK, has been associated with more aggressive breast cancer phenotypes and poor patient prognosis (Ross \& Fletcher 1998, Arteaga 2001). These pathways have additionally been linked to the tamoxifen resistance phenotype (Benz et al. 1993, Kurokawa et al. 2000, Gee et al. 2001, Kurokawa \& Arteaga 2003, Shou et al. 2004). The evidence presented here suggests that modulation of $\mathrm{ER} \alpha$ phosphorylation can determine whether or not tamoxifen acts as an ER $\alpha$ agonist or antagonist, and that hyperphosphorylation may result in tamoxifen-induced activities at levels high enough to support the growth of cells that depend upon ER $\alpha$ activity, such as those found in the majority of breast cancers.

\section{Acknowledgements}

We thank the members of the laboratory for helpful discussions, and Dr L Buluwela for discussion of the work and critical reading of this manuscript. This work was made possible by grants from Cancer Research UK and the Breast Cancer Research Trust. The authors declare that there is no conflict of interest that would prejudice the impartiality of this scientific work.

\section{References}

Ali S \& Coombes RC 2002 Endocrine-responsive breast cancer and strategies for combating resistance. Nature Review Cancer 2 101-112.

Ali S, Metzger D, Bornert JM \& Chambon P 1993 Modulation of transcriptional activation by ligand-dependent phosphorylation of the human oestrogen receptor A/B region. EMBO Journal 12 1153-1160.

Arteaga CL 2001 The epidermal growth factor receptor: from mutant oncogene in nonhuman cancers to therapeutic target in human neoplasia. Journal of Clinical Oncology 19 32S-40S.

Beato M, Herrlich P \& Schutz G 1995 Steroid hormone receptors: many actors in search of a plot. Cell 83 851-857.

Benz CC, Scott GK, Sarup JC, Johnson RM, Tripathy D, Coronado E, Shepard HM \& Osborne CK 1993 Estrogen-dependent, tamoxifenresistant tumorigenic growth of MCF-7 cells transfected with HER2/neu. Breast Cancer Research and Treatment 24 85-95.

Berry M, Metzger D \& Chambon P 1990 Role of the two activating domains of the oestrogen receptor in the cell-type and promotercontext dependent agonistic activity of the anti-oestrogen 4-hydroxytamoxifen. EMBO Journal 9 2811-2818.

Bjornstrom L \& Sjoberg M 2005 Mechanisms of estrogen receptor signaling: convergence of genomic and nongenomic actions on target genes. Molecular Endocinology 19 833-842.

Bocquel MT, Kumar V, Stricker C, Chambon P \& Gronemeyer H 1989 The contribution of the $\mathrm{N}$ - and C-terminal regions of steroid receptors to activation of transcription is both receptor and cellspecific. Nucleic Acid Research 17 2581-2595. 
Brzozowski AM, Pike AC, Dauter Z, Hubbard RE, Bonn T, Engstrom O, Ohman L, Greene GL, Gustafsson JA \& Carlquist M 1997 Molecular basis of agonism and antagonism in the oestrogen receptor. Nature $389753-758$.

Bunone G, Briand PA, Miksicek RJ \& Picard D 1996 Activation of the unliganded estrogen receptor by EGF involves the MAP kinase pathway and direct phosphorylation. EMBO Journal 15 2174-2183.

Campbell RA, Bhat-Nakshatri P, Patel NM, Constantinidou D, Ali S \& Nakshatri H 2001 Phosphatidylinositol 3-kinase/AKT-mediated activation of estrogen receptor $\alpha$ : a new model for anti-estrogen resistance. Journal of Biological Chemistry 276 9817-9824.

Chen D, Riedl T, Washbrook E, Pace PE, Coombes RC, Egly JM \& Ali S 2000 Activation of estrogen receptor alpha by S118 phosphorylation involves a ligand-dependent interaction with TFIIH and participation of CDK7. Molecular Cell 6 127-137.

Chen D, Washbrook E, Sarwar N, Bates GJ, Pace PE, Thirunuvakkarasu V, Taylor J, Epstein RJ, Fuller-Pace FV, Egly JM et al. 2002 Phosphorylation of human estrogen receptor alpha at serine 118 by two distinct signal transduction pathways revealed by phosphorylation-specific antisera. Oncogene 21 4921-4931.

Couse JF \& Korach KS 1999 Estrogen receptor null mice: what have we learned and where will they lead us? Endocrine Reviews 20 358-417.

Curtis SW, Washburn T, Sewall C, DiAugustine R, Lindzey J, Couse JF \& Korach KS 1996 Physiological coupling of growth factor and steroid receptor signaling pathways: estrogen receptor knockout mice lack estrogen-like response to epidermal growth factor. PNAS93 12626-12630.

Gee JM, Robertson JF, Ellis IO \& Nicholson RI 2001 Phosphorylation of ERK1/2 mitogen-activated protein kinase is associated with poor response to anti-hormonal therapy and decreased patient survival in clinical breast cancer. International Journal of Cancer 95 247-254.

Glass CK \& Rosenfeld MG 2000 The coregulator exchange in transcriptional functions of nuclear receptors. Genes and Development 14 121-141.

Le Goff P, Montano MM, Schodin DJ \& Katzenellenbogen BS 1994 Phosphorylation of the human estrogen receptor. Identification of hormone-regulated sites and examination of their influence on transcriptional activity. Journal of Biological Chemistry 269 4458-4466.

Gronemeyer H 1991 Transcription activation by estrogen and progesterone receptors. Annual Review of Genetics 25 89-123.

Henderson IC \& Piccart-Gebhart MJ 2005 The evolving role of aromatase inhibitors in adjuvant breast cancer therapy. Clinical Breast Cancer 6 206-215.

Ignar-Trowbridge DM, Nelson KG, Bidwell MC, Curtis SW, Washburn TF, McLachlan JA \& Korach KS 1992 Coupling of dual signaling pathways: epidermal growth factor action involves the estrogen receptor. PNAS $894658-4662$

Ignar-Trowbridge DM, Teng CT, Ross KA, Parker MG, Korach KS \& McLachlan JA 1993 Peptide growth factors elicit estrogen receptordependent transcriptional activation of an estrogen-responsive element. Molecular Endocinology 7 992-998.

Ignar-Trowbridge DM, Pimentel M, Parker MG, McLachlan JA \& Korach KS 1996 Peptide growth factor cross-talk with the estrogen receptor requires the $\mathrm{A} / \mathrm{B}$ domain and occurs independently of protein kinase C or estradiol. Endocrinology 137 1735-1744.

Joel PB, Traish AM \& Lannigan DA 1995 Estradiol and phorbol ester cause phosphorylation of serine 118 in the human estrogen receptor. Molecular Endocinology 9 1041-1052.

Joel PB, Smith J, Sturgill TW, Fisher TL, Blenis J \& Lannigan DA $1998 a$ pp90rsk1 regulates estrogen receptor-mediated transcription through phosphorylation of Ser-167. Molecular Cell Biology 18 1978-1984.

Joel PB, Traish AM \& Lannigan DA $1998 b$ Estradiol-induced phosphorylation of serine 118 in the estrogen receptor is independent of p42/p44 mitogen-activated protein kinase. Journal of Biological Chemistry 273 13317-13323.

Kato S, Endoh H, Masuhiro Y, Kitamoto T, Uchiyama S, Sasaki H, Masushige S, Gotoh Y, Nishida E, Kawashima H et al. 1995 Activation of the estrogen receptor through phosphorylation by mitogenactivated protein kinase. Science 270 1491-1494.
Kurokawa H \& Arteaga CL 2003 ErbB (HER) receptors can abrogate antiestrogen action in human breast cancer by multiple signaling mechanisms. Clinical Cancer Research 9 511S-515S.

Kurokawa H, Lenferink AE, Simpson JF, Pisacane PI, Sliwkowski MX, Forbes JT \& Arteaga CL 2000 Inhibition of HER2/neu (erbB-2) and mitogen-activated protein kinases enhances tamoxifen action against HER2-overexpressing, tamoxifen-resistant breast cancer cells. Cancer Research 60 5887-5894.

Lipfert L, FisherJE, Wei N, Scafonas A, Su Q, YudkovitzJ, Chen F, Warrier S, Birzin ET, Kim S et al. 2006 Antagonist-induced, AF-2 independent estrogen receptor $\alpha$ phosphorylation. Molecular Endocinology 20 516-533.

McDonnell DP, Clemm DL, Hermann T, Goldman ME \& Pike JW 1995 Analysis of estrogen receptor function in vitro reveals three distinct classes of antiestrogens. Molecular Endocinology 9 659-669.

Medunjanin S, Hermani A, De Servi B, Grisouard J, Rincke G \& Mayer D 2005 Glycogen synthase kinase-3 interacts with and phosphorylates estrogen receptor $\alpha$ and is involved in the regulation of receptor activity. Journal of Biological Chemistry 280 33006-33014.

Metzger D, Losson R, Bornert JM, Lemoine Y \& Chambon P 1992 Promoter specificity of the two transcriptional activation functions of the human oestrogen receptor in yeast. Nucleic Acid Research 20 2813-2817.

Nettles KW \& Greene GL 2005 Ligand control of coregulator recruitment to nuclear receptors. Annual Review of Physiology 67 309-333.

Obenauer JC, Cantley LC \& Yaffe MB 2003 Scansite 2.0: proteome-wide prediction of cell signaling interactions using short sequence motifs. Nucleic Acid Research 31 3635-3641.

Osborne CK 1998 Tamoxifen in the treatment of breast cancer. New England Journal of Medicine 339 1609-1618.

Pietras RJ, Arboleda J, Reese DM, Wongvipat N, Pegram MD, Ramos L, Gorman CM, Parker MG, Sliwkowski MX \& Slamon DJ 1995 HER-2 tyrosine kinase pathway targets estrogen receptor and promotes hormone-independent growth in human breast cancer cells. Oncogene 10 2435-2446.

Rogatsky I, Trowbridge JM \& Garabedian MJ 1999 Potentiation of human estrogen receptor alpha transcriptional activation through phosphorylation of serines 104 and 106 by the cyclin A-CDK2 complex. Journal of Biological Chemistry 274 22296-22302.

Ross JS \& Fletcher JA 1998 The HER-2/neu oncogene in breast cancer: prognostic factor, predictive factor, and target for therapy. Stem Cells 16 413-428.

Sarwar N, Kim JS, Jiang J, Peston D, Sinnett HD, Madden P, Gee JM, Nicholson RI, Lykkesfeldt AE, Shousha S et al. 2006 Phosphorylation of $\mathrm{ER} \alpha$ at serine 118 in primary breast cancer and in tamoxifen-resistant tumours is indicative of a complex role for $\mathrm{ER} \alpha$ phosphorylation in breast cancer progression. EndocrineRelated Cancer 13 851-861.

Shang Y \& Brown M 2002 Molecular determinants for the tissue specificity of SERMs. Science 295 2465-2468.

Shiau AK, Barstad D, Loria PM, Cheng L, Kushner PJ, Agard DA \& Greene GL 1998 The structural basis of estrogen receptor/coactivator recognition and the antagonism of this interaction by tamoxifen. Cell 95 927-937.

Shou J, Massarweh S, Osborne CK, Wakeling AE, Ali S, Weiss H \& Schiff R 2004 Mechanisms of tamoxifen resistance: increased estrogen receptor-HER2/neu cross-talk in ER/HER2-positive breast cancer. Journal of National Cancer Institute 96 926-935.

Smith CL 1998 Cross-talk between peptide growth factor and estrogen receptor signaling pathways. Biology of Reproduction $\mathbf{5 8}$ 627-632.

Smith CL, Nawaz Z \& O'Malley BW 1997 Coactivator and corepressor regulation of the agonist/antagonist activity of the mixed antiestrogen, 4-hydroxytamoxifen. Molecular Endocinology 11 $657-666$. 
Tora L, Mullick A, Metzger D, Ponglikitmongkol M, Park I \& Chambon P $1989 a$ The cloned human oestrogen receptor contains a mutation which alters its hormone binding properties. EMBO Journal 8 1981-1986.

Tora L, White J, Brou C, Tasset D, Webster N, Scheer E \& Chambon P $1989 b$ The human estrogen receptor has two independent nonacidic transcriptional activation functions. Cell 59 477-487.

Trowbridge JM, Rogatsky I \& Garabedian MJ 1997 Regulation of estrogen receptor transcriptional enhancement by the cyclin A/Cdk2 complex. PNAS 94 10132-10137.

Tsai MJ \& O'Malley BW 1994 Molecular mechanisms of action of steroid/thyroid receptor superfamily members. Annual Review of Biochemistry 63 451-486.
Tzukerman MT, Esty A, Santiso-Mere D, Danielian P, Parker MG, Stein RB, Pike JW \& McDonnell DP 1994 Human estrogen receptor transactivational capacity is determined by both cellular and promoter context and mediated by two functionally distinct intramolecular regions. Molecular Endocinology 8 21-30.

Received in final form 8 February 2008 Accepted 19 February 2008

Made available online as an Accepted Preprint 19 February 2008 